\title{
Determinants of Corruption in Developing Countries: The Limits of Conventional Economic Analysis
}

Mushtaq H. Khan

(published in Susan Rose-Ackerman ed. (2006). International Handbook on the Economics of Corruption. Cheltenham: Edward Elgar).

Corruption takes place when public officials break the law in pursuit of their private interest. But public officials can break different laws in different ways with different implications for the public good. The factors driving corruption and the effects of corruption can therefore vary widely. Understanding the causes and consequences of corruption is particularly important in developing countries, which almost without exception suffer from high levels of corruption. The virtual uniformity of this evidence strongly suggests that developing countries must share some powerful common drivers of corruption that are different from those that affect advanced industrial countries. At the same time, the very diverse economic performance of developing countries suggests that not all developing countries suffer from the same types of corruption. These two observations, summarized in our first section, provide the backdrop to my analytical investigation. I begin this investigation by identifying the drivers of corruption implicit in most conventional neoclassical economic analysis of the topic. Although these drivers are undoubtedly important in many contexts, I next argue that a number of other drivers of corruption may be more important in developing countries. These countries have several critical structural features that are recognized in the broader social science literature but the implications of these features for the economic analysis of corruption have not been adequately developed. We argue that the types of corruption generated by these structural features of developing countries are much less amenable to the types of anti-corruption measures that are prescribed by the conventional analysis of corruption. I then use this analysis to provide an alternative classification of types of corruption in developing countries and suggest that policy has to be appropriate to the drivers of corruption most relevant in particular countries. The implications of this analysis for anti-corruption strategies in developing countries are discussed in the final section. 


\section{Corruption in Developing Countries: the Evidence}

The evidence from across the developing world tells us there are very few developing countries that have low levels of corruption. The few low-corruption developing countries tend to be exceptional and are not necessarily the fastest growing developers. Although there are many problems with subjective corruption indices, they suffice to show the broad features of the problem. The earliest year for which corruption data are available across a broad range of countries is 1984, and we use the corruption indices provided by the IRIS center at the University of Maryland. This index ranges from 0 (the highest level of corruption) to 6 (the lowest level). Data are available for 85 countries. Table 1 summarizes the data and the per capita GDP growth rate of these countries over the period 1980-90 with the population split into three groups. The advanced industrialized countries are the first group. These countries have relatively low corruption indices and moderate rates of growth. Developing countries are split into two groups: a group of converging developers whose per capita growth rate is higher than the advanced country average, and a third group of developing countries with growth rates below the advanced country average, which were consequently falling behind in relative terms.

Table 1 shows that there is virtually no difference in the median level of corruption between high-growth and low-growth developing countries. The same data are shown graphically in Figure 1. The low-growth countries are more than four times as numerous as the high-growth countries, and so it is not entirely surprising that their corruption indices show a greater range of variation. Apart from that, there is no discernible pattern in the figures except that developing countries on average seem to suffer from higher levels of corruption compared to advanced countries. 
Table 1 Corruption and Growth 1980-90

Median Corruption Index 1984

(Range)

Advanced

Industrialized

Countries

$n=21$

Converging

Developers

$$
\mathrm{n}=12
$$

Other Developing

Countries

$\mathrm{n}=52$

\section{4}

$(3-6)$

3

(1-5)

2.6

(0-6)
Median per capita growth rate

1980-90

(Range)

$$
2.2
$$

$-1.0$

$(-6.3-2)$

Source: IRIS-3 (2000), World Bank (1992). The corruption index ranges from 0 for maximum corruption to 6 for minimum corruption.

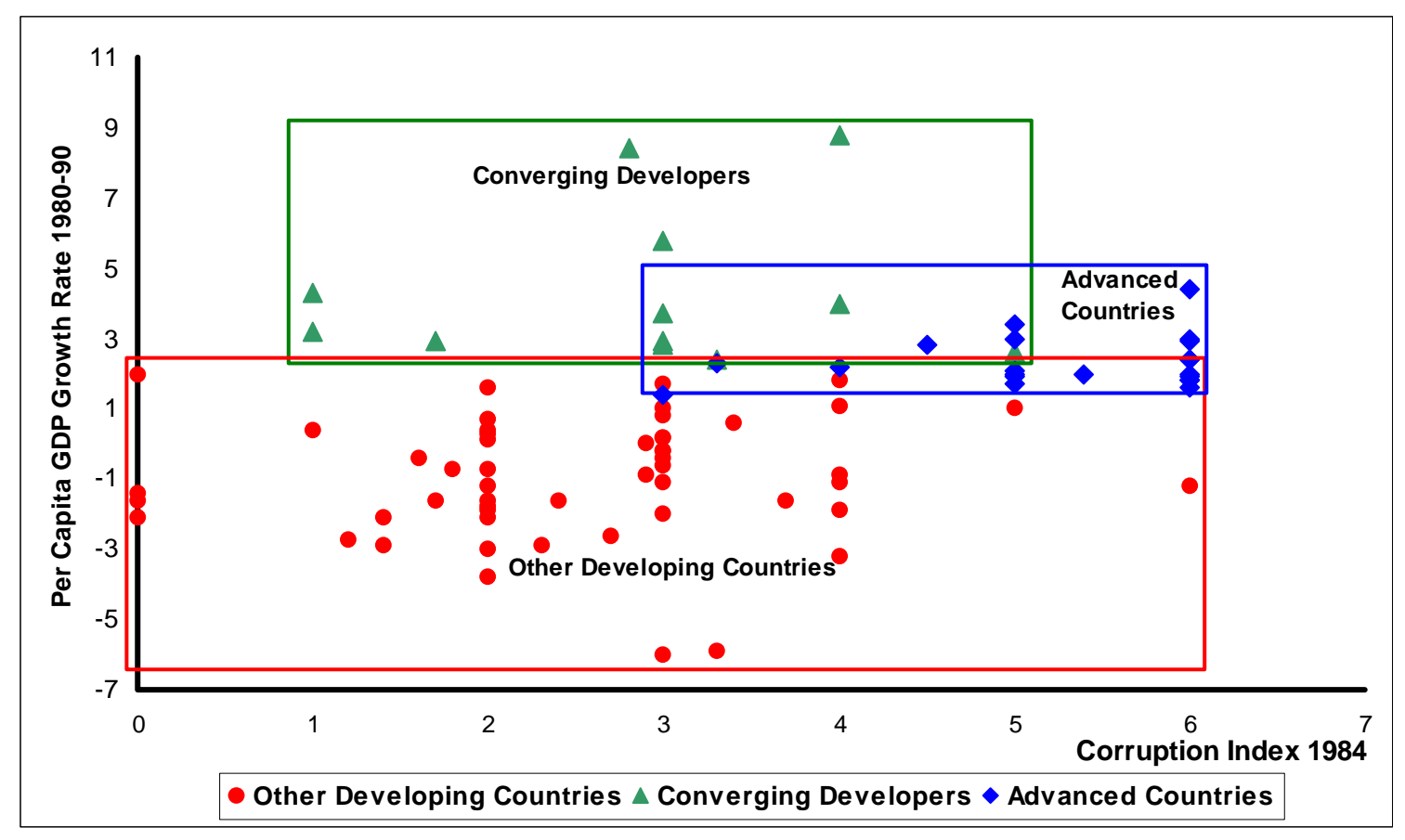

Source: IRIS-3 (2000), World Bank (1992).

Figure 1 Corruption and Growth 1980-90

Thus, two observations stand out in the table and in the scatter diagram. First, advanced industrialized economies tend to have lower levels of corruption than developing economies. This suggests that the level of development may be an important determinant of the chances of reducing corruption. Secondly, within the 
group of poorer economies, the median country in the high-growth developing country group does not have significantly lower corruption levels than the median country in the group that is falling behind. Given the obviously damaging effects of corruption in many contexts, we read this observation not as saying that corruption has no effect on economic performance, but rather that corruption is likely to have very different effects in different contexts. These observations will inform our investigation of the economic analysis of corruption and the relevance of the drivers of corruption identified in much of the literature that is influencing policy-making in developing countries.

An inspection of the data is particularly important given the growing number of sophisticated econometric studies that find some relationship between corruption and economic performance (many of these are reviewed in Lambsdorff 2005 and Kaufmann and Kraay this volume). Finding a relationship, however, does not tell us anything about causation. We need to examine the theoretical arguments closely before accepting the link between corruption and economic performance that has been suggested by a number of frequently quoted econometric studies (Knack and Keefer 1995; Mauro 1995; Knack and Keefer 1997; Mauro 1997; Johnson, et al. 1998; Hall and Jones 1999; Kauffman, et al. 1999). These studies typically establish a strong relationship between corruption (and other governance indicators) and per capita incomes. This is entirely consistent with the data showing a significant difference in the corruption index between advanced and developing countries. However, for corruption to be a policy target we need to establish a causal relationship going from corruption to economic growth. This relationship is typically rather weak and often disappears with the inclusion of variables such as the investment rate (Mo 2001). This too is consistent with the crude data and suggests that the causal relationship between corruption and economic performance is too unreliable to be the basis of significant policy efforts without further investigation of the underlying theory (Khan 2004). In the next four sections, we identify four different types of corruption in developing countries, the factors driving their emergence and persistence, the likely economic effects of each and the likely countermeasures that could be adopted. We argue that although all developing countries have high corruption in the aggregate, the mix of types of corruption that prevails differs widely, and this divergence helps to explain the very different net effects of corruption across developing countries. 


\section{'Neoclassical' Corruption: Seeking Bribes through Damaging Interventions}

The most commonly used models of corruption derived from neoclassical economics assume that corruption is driven by the legal powers of the state that give public officials the ability to disrupt otherwise efficient markets. This allows them to create rents or obstacles for private investors and citizens, in most cases, acting inside the law. These powers give public officials the ability to bargain for kickbacks or bribes in exchange for allocating rents to those who can pay for them or removing obstacles in the path of those who would rather pay than suffer delay or obstruction (Klitgaard 1988; Rose-Ackerman 1978 and 1999; Shleifer and Vishny 1993). The kickbacks and bribes are, of course, illegal, and constitute corruption. Although the ability to create rents and restrictions is important, public officials must also have the incentive to break the law by seeking bribes in these ways, which means that the expected benefit to the official of engaging in corruption has to be greater than the expected cost of the potential punishment.

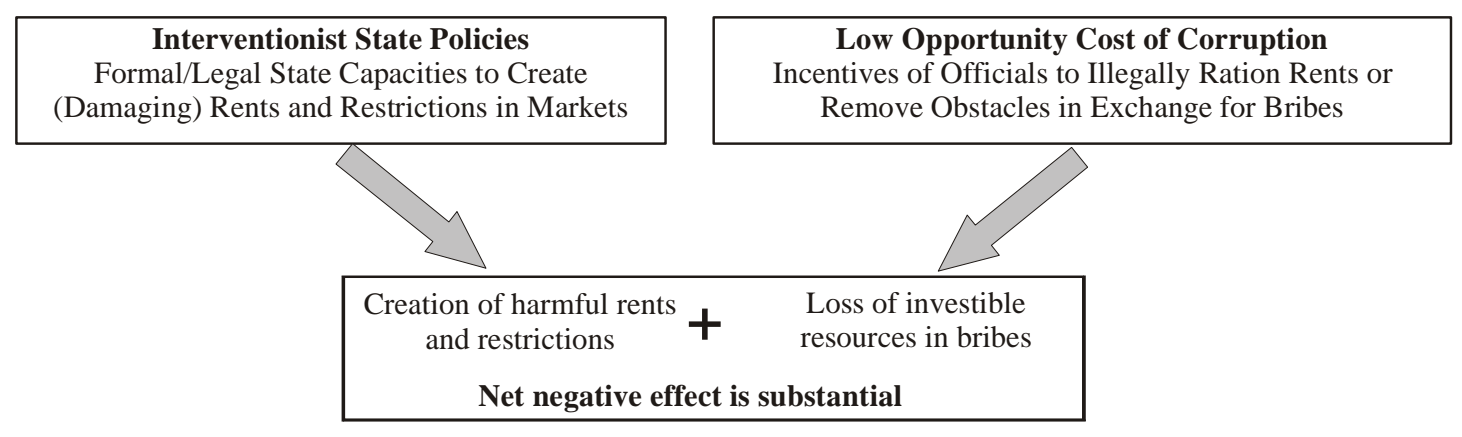

Figure 2 Drivers and Effects of 'Neoclassical' Corruption

The two critical drivers of what we will call 'neoclassical' corruption are shown in Figure 2. First, this type of corruption requires the existence of formal state capacities so that public officials can legally create rents of different types, or impose obstacles to the operation of markets. The creation of rents means that some potential beneficiaries will be willing to pay a price to get access to these rents, and similarly, the creation of obstacles means that some market actors will be willing to pay to avoid them. The formal powers of the state to create rents and restrictions thus create the potential for corruption. But for corruption to take place, a second condition is that public officials must have the incentive to break the law and allocate these rents for a 
price to those who can pay for them, or to remove obstacles for those who can afford to pay for their removal. Because this part of the exchange is typically illegal (and therefore constitutes corruption), public officials must have a low opportunity cost of being caught in the act. The opportunity cost of being caught and losing the public position is low if the salary of the public official is low, if risk of detection is low, and if the probability of being found guilty and being punished is low even after detection. Because these conditions are commonly observed in most developing countries, the formal ability of the state to create rents and restrictions in markets leads to widespread corruption.

The obstacles and rents created by public officials seeking bribes can range from the unnecessary red tape and paper pushing that takes on iconic proportions in many developing countries, to the creation of monopolies, tariffs, subsidies and other damaging rents that are both directly damaging for the economy, as well as creating rent-seeking opportunities for public officials and others. Excessive regulation and requirements of permissions often have no purpose except to enable bureaucrats to extract bribes from the private sector. This type of corruption also includes "petty corruption” involving low-level officials extracting small bribes for performing their duties (speed money), or for not harassing the innocent by deliberately misinterpreting very complex and unclear regulations (customs officials or police engaging in petty extortion).

This is often the most visible face of corruption in developing countries and, in opinion surveys, public irritation with these types of corruption often dominates. Police corruption, for example, often takes top position in popular perceptions of the worst types of corruption. Some police corruption is petty corruption where traffic police (like customs officials and other low level bureaucrats) find opportunities for corruption while implementing complex and poorly defined laws. Although these types of corruption are very irksome and can affect a great number of people, they are not necessarily the most damaging type of corruption for the economy. Nevertheless, petty corruption is damaging, the payoffs are regressive in that the victims are very often the poor, and they increase transaction costs and the general perception of lawlessness in developing countries. Of course, police corruption and bureaucratic corruption can be much more serious and predatory, as we will see later. 
When these types of restrictions and laws exist, some corruption can actually enable investors and ordinary citizens to avoid damaging obstacles that impede the operation of the market. Indeed at one time, it was argued that in a second-best sense, some corruption of this type could be efficiency enhancing given the context (Leff 1964; Huntington 1968). However, the ability of the state to make unnecessary laws can encourage the creation of more and more artificial restrictions and more and more red tape to increase opportunities for extraction (Myrdal 1968: 937-51). The social waste associated with this could be considerable according to some models of these processes (Krueger 1974). Nor can corruption be restricted only to those areas where the effects may be desirable even in a second-best sense (Rose-Ackerman 1978). Today the consensus is that for corruption of this type, the best policy would be to remove the unnecessary restrictions, rather than hope that corruption would enable the economy to work its way around these obstacles.

The economic cost of this corruption is twofold. First, there is a rent-seeking cost, which is the cost of the resources used up in seeking the rents or overcoming the restrictions. This includes the loss of potentially investible resources in bribes transferred to public officials, who are assumed to use them less efficiently, leading to a reduction in investment. It also includes other resources that are used up, for instance by public officials seeking to maintain their positions in lucrative parts of the bureaucracy. Second, there is a social cost due to the rents and restrictions created by public officials. The damaging rents that states can create include monopoly rents, import restrictions that generate monopoly rents, subsidies to infant industries that never grow up, and transfers and subsidies to special interest groups. Each of these generates deadweight losses for society. Similarly, restrictions and obstacles in markets increase transaction costs and result in efficiency losses. The effects of these rents and restrictions are therefore reductions in economic efficiency and deadweight welfare losses that can result in further reductions of investment. The overall effect of corruption is the sum of these two different effects, the loss of resources in rent seeking and the adverse effects of the rents and interventions created by bribe-seeking public officials. The overall negative effect of this type of corruption (shown in Figure 2) is therefore likely to be significant (Khan 1996a, 2000b). 
The policy advice that derives from the analysis of this type of corruption targets both sets of drivers. First, corruption of this type is likely to be reduced if the discretionary legal capacity of public officials to impose restrictions or create rents can be reduced through liberalization, privatization and reforms to "rightsize" the state so that it only provides essential public services. Secondly, corruption will also be reduced if the opportunity cost of corruption can be raised. This can be achieved through higher salaries for public officials (financed if necessary by reducing their overall number), greater transparency in the allocation of public resources and more effective judicial processes for dealing with those charged with corruption (World Bank 1997, 2000). These measures increase the expected cost of engaging in corrupt acts, and are likely to reduce the incidence of corruption.

However, the empirical results tracing the impact of such policy interventions on the level of corruption have produced very limited results. Contrary to the policy analysis discussed above, observations of developing countries show that the mix between public and private sectors, interventionist or liberal economic policies, the presence or absence of democracy, the degree of centralization or decentralization of government or the salaries of public officials have relatively little effect on the overall extent of corruption. Developing countries that follow policies of low intervention and have active civil society participation in politics do not tend to have significantly lower corruption than those that have more interventions or have authoritarian political regimes (Treisman 2000; Khan 2002). To make sense of this evidence and to come up with better policy responses, we need to look at a number of other possible drivers of corruption in developing countries.

\section{'Statist' Corruption: Seeking Bribes with Potentially Beneficial Interventions}

A significant underlying assumption in the 'neoclassical' analysis of corruption is that in seeking bribes, public officials primarily create damaging rents and market restrictions. The implicit assumption is that the range of necessary public goods that states need to provide for market economies to operate efficiently is rather limited. This assumption is important for simplifying the analysis, so that the capacity of the state to intervene is itself one of the drivers of the neoclassical corruption summarized in Figure 2. However, if the range of potentially beneficial state interventions is a wide one, there is a possibility that there may be different types of corruption with 
different effects. In this case, the drivers explaining the dominance of different types of corruption are inevitably more complex than in the simple model discussed earlier.

In fact, neoclassical economics recognizes a wide range of market failures and, therefore, acknowledges the possibility of potentially beneficial state interventions. These beneficial interventions are in turn very likely to create rents and market restrictions, but in this case, the creation of these rents may represent significant second-best improvements. The importance of some of these rents has been pointed out by asymmetric information economics, which established that a range of rents may be beneficial and even necessary for the operation of market economies in the context of asymmetric information (Stiglitz 1996). Heterodox economics looking at late developers has identified an even wider range of rents and interventions that can potentially accelerate economic development if properly managed. These include rents that can create additional incentives for accelerating the acquisition of new technologies or help development by maintaining political stability (Amsden 1989; Wade 1990; Rodrik 1995; Aoki, et al. 1997; Lall and Teubal 1998; Woo-Cumings 1999; Khan and Jomo 2000; Khan 2002; Rodrik 2002; Khan 2004).

The possibility of growth-enhancing rents and interventions raises a number of critical questions for the analysis of corruption in developing countries. If a range of beneficial rents can be created by states, this gives the state discretionary powers to determine which of these rents will be created, how they will be allocated and what conditions have to be fulfilled for beneficiaries to continue to receive these rents. Some rent seeking will inevitably follow although the rent seeking cost can vary depending on institutional and political conditions (Khan 2000b). Some of this rent seeking can take the form of corruption, particularly in developing countries where the opportunity cost of corruption is low. But under these conditions, corruption can potentially have ambiguous effects. Unlike the simple case of neoclassical corruption shown in Figure 2 where both the rent the state creates and the rent-seeking cost in the form of bribes have a negative effect, in the case of statist corruption there are two offsetting effects.

The rent or restriction created may now have a positive effect that may offset the negative economic effect of bribes and other rent seeking costs. The type of 
intervention and rent created now becomes of critical significance. The beneficial effect of the intervention may even be large enough to offset the negative effect of the bribe, such that the net effect of the intervention is now positive. "Positive" in this context means that society would be worse off without the intervention than with the intervention including the negative effects of corruption. Of course, society would be even better off if the intervention could be organized without any corruption, but it would be unrealistic to assume that an intervention that creates a rent can be managed without a rent-seeking cost. Even if the corruption could be replaced with legal rent seeking, there would still be a rent-seeking cost, but in just the same way, society may be better off with these beneficial interventions even if they entail significant rentseeking costs (Khan 1996a, 2000a, 2000b). It is always preferable to replace corruption with legal rent seeking if only because the latter can be regulated to ensure that its damaging effects are minimized. The policy challenge is then not one of organizing liberalization, but of strengthening state capacities for beneficial intervention, converting any illegal rent seeking into legal forms and regulating this rent seeking to ensure that the beneficial aspects of the intervention are maximized.

Figure 3 shows the drivers and effects of what I call 'statist' corruption. The outcome depends critically on the political economy of rent management. This is the process of rent seeking through which the types of interventions and associated rents are determined, together with the absorption of resources in different forms of rent seeking including both bribes and legal forms of rent seeking, such as lobbying, political contributions and so on. We can distinguish between two quite different possibilities as shown in Figure 3. Value-enhancing outcomes, shown along the lefthand fork arise if the political economy of the rent creation process permits the creation and effective management of rents that create incentives for economic growth, and if the resource cost of rent seeking or corruption does not outweigh this benefit. In this case, economic development can coexist with substantial corruption, or in the absence of corruption, with substantial rent seeking. Corruption operates here as a tax that public officials collect from the growth-generating beneficiaries of rents. In the case of legal rent seeking, rent seekers contribute to political parties or hire lobbyists. As it is likely that a growing economy will allow more bribes or legal benefits for public officials over time, we can assume that, ceteris paribus, public officials (if they could act collectively) would prefer this outcome. Value-enhancing 
state intervention coexisting with substantial corruption is frequently observed in high-growth developing countries such as South Korea in the sixties, or in contemporary China (Khan 1996b). Legal rent seeking by dynamic producers in advanced countries (for instance to protect their innovation rents or to lobby for tax breaks) is generally also of this variety.

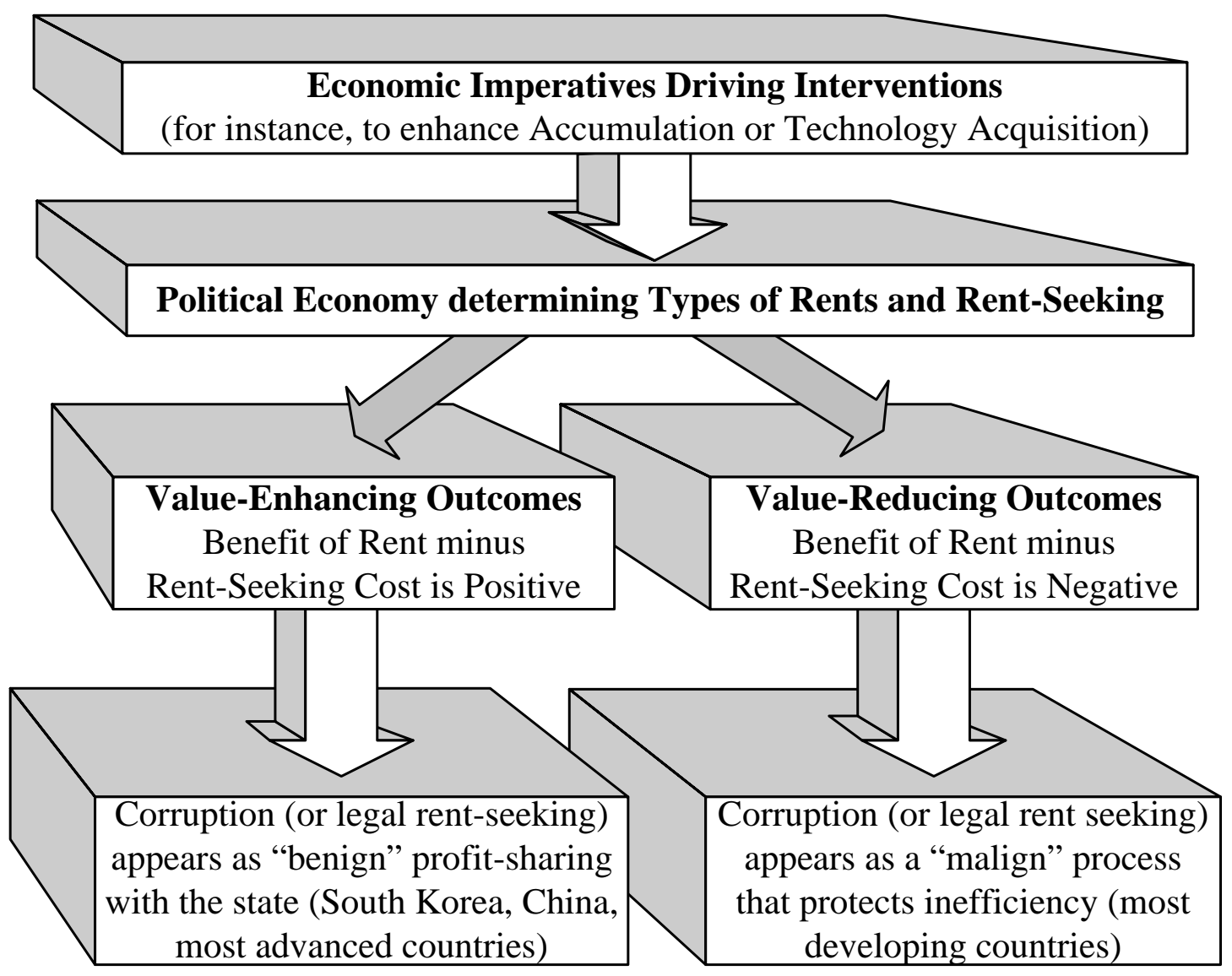

Figure 3 Drivers and Effects of Statist Corruption

In contrast, the right-hand fork in Figure 3 shows that value-reducing outcomes are also possible, where the net effect of rent management is negative. This could either be because the cost of the rent seeking is too high, or more likely, that the rents themselves are damaging. The damaging rents in this case are potentially beneficial rents that are poorly managed and allocated. The overall effect together with the rentseeking cost is negative, just as in the pure neoclassical case. Indeed, the two can be difficult to distinguish because potentially beneficial rents can have damaging effects if they are badly managed or allocated. For example, a potentially valuable subsidy for technology acquisition can become a damaging rent if inefficient subsidy 
recipients fail to acquire technology and are able to pay to keep the subsidy in place even though it is ineffective. The effect of this rent is the same as if public officials had created wasteful subsidies in the first place, and used their capacity to allocate these rents to extract bribes from subsidy recipients. Thus, cases of corruption that appear to be neoclassical corruption (where damaging rents are deliberately created to extract bribes) may be difficult to distinguish from corruption associated with failed statist interventions where states fail to manage potentially beneficial rents effectively so that the rents appear to be damaging ex post.

Comparing the two types of outcomes in Figure 3, the paradox in the case of valuereducing outcomes is that the total bribes collected here may often be lower than in the case of value-enhancing outcomes where developmental rents are effectively implemented. We can assume that if public officials could determine the political economy of rent management, they would collectively prefer to achieve valueenhancing outcomes, if only because this would maximize the bribes or legal benefits that they could collect over time. This is a stronger version of Andrei Shleifer and Robert Vishny's (1993) conclusion that coordinated corruption is less damaging than uncoordinated corruption. It follows that if public officials have the power to create rents; their decision to create damaging rather than beneficial rents has to be explained because they could in theory benefit even more from the latter. One possibility is that state institutions are fragmented and individual public officials create rents to collect bribes for themselves and are unable to coordinate with other officials to maximize the total bribe. This is the explanation that Shleifer and Vishny (1993) suggest, although their model is one of neoclassical corruption where the rents created are always damaging. Nevertheless, they show that coordination to maximize the bribe collected can limit the creation of damaging rents. If states can create beneficial rents as well, the effect of a failure to coordinate state agencies would be even stronger. Another possibility is that rent-seeking factions in society are powerful but fragmented, so that factions can veto re-allocations of rents away from themselves regardless of the social cost (Khan 1996b). For instance, it may be potentially very beneficial to provide emerging entrepreneurs with tax breaks or other resources to accelerate their acquisition of new technology. However, if inefficient capitalists can easily join political factions that can exert pressure to protect their subsidies regardless of efficiency, a potentially beneficial policy can be subverted by what 
appears to be corruption. In fact, the inefficiency-generating corruption is only a manifestation of a deeper problem, the fragmentation of political power. Unless reforms can restructure political organizations, anti-corruption strategies by themselves will not achieve much because legal rent seeking will be almost as harmful as illegal payoffs in these cases.

An analysis of the drivers of statist corruption shows that the policy recommendations coming from the neoclassical analysis of corruption can be counterproductive. If the rent-creating intervention of the state can be potentially beneficial for the economy, removing or limiting the rent-creation capacities of the state may be inappropriate. This would obviously be true for those cases where corruption was associated with value-enhancing interventions (the left hand fork in Figure 3). Even in these cases, corruption is a social cost and is certainly not functional, as used to be argued by some early analysts (such as Leff 1964). But even if corruption is a social cost, the appropriate social response should be to try to regulate and reduce the cost of the rent seeking, not to do away with the rents. Zero corruption could be achieved by removing the relevant rent creation capacities of the state, but society would be worse off as a result.

The more interesting question arises in the cases (unfortunately the majority) where the underlying political economy of rent management subverts decisions about the types of rents to be created and their allocation so that the outcome is value reducing (the right hand fork in Figure 3). Here the neoclassical response of limiting state capacities may appear to be appropriate because in these cases it would be arithmetically true that shutting down both the rent and the associated corruption would leave society better off. But closer reflection suggests that in many cases this response would be inappropriate. It would only make sense to scale back the interventionist capacities of the state if nothing could be done to address the underlying political economic situation. If something can be done, then addressing the political economy drivers responsible for subverting potentially beneficial interventions may be more fruitful for society than to respond as if the problem was one of neoclassical corruption. 


\section{Political Corruption and Clientelism}

Neoclassical and statist corruption each raise different policy challenges, but they are both essentially driven by states that legally create rents and public officials who illegally benefit from the associated rent seeking. In contrast, the drivers of political corruption in developing countries raise some entirely new issues. These drivers derive from the imperatives of political stabilization in the context of underdevelopment. Political stabilization in any country entails the redistribution of incomes. But in advanced industrialized countries, the process through which this redistribution is achieved has characteristics that are quite different from those of the typical developing country. Two of these differences are significant, and together, they help to explain why political stabilization in advanced countries can typically be achieved through transparent redistributions through the fiscal process. In contrast, political stabilization in developing countries typically involves off-budget transfers that usually involve political corruption.

The first and most obvious difference between countries at different levels of development is that richer countries with large productive sectors in the regulated or formal sector find it much easier to collect a significant share of national income in taxes. This allows advanced countries to respond to political organizations demanding redistribution with a range of transparent and legal transfers and public service delivery. In contrast, countries where the formal or modern sector is still small find that not only is their national income small, but also they can typically tax a much smaller share of this smaller income. In many of the poorest developing countries, the budget is in deficit after the salaries of public employees have been paid. In the more developed of the developing countries, tax income may partially cover some of the spending on infrastructure, but even in these countries, much of the investment in infrastructure is typically financed by borrowing or aid. In most developing countries, very little tax revenue remains for financing redistribution. At the same time, developing countries typically face more serious problems of internal political conflict than advanced countries, given the wrenching social transformations that they are experiencing. This means that political stabilization cannot be organized through the public fisc in most developing countries. 
Second, not only do advanced countries have significant tax revenues to achieve political stabilization, they also enjoy powerful internal feedback mechanisms that prevent or limit political demands that pose sustained threats to the viability of the productive sector. The main reason for this is that in advanced industrialized countries the standard of living of a significant proportion of the population depends directly or indirectly on the health of the capitalist sector. Apart from the capitalists and workers directly involved in this sector, the wellbeing of professionals, public sector employees and the self-employed depend on the taxes or the purchasing power of the capitalist sector. This means that although organized groups have every interest in pushing for redistribution to themselves, if their collective demands begin to restrict the growth of the productive sector, powerful feedback mechanisms begin to operate because all groups begin to lose out from the economic slowdown. This mechanism is not perfect, and there are clearly occasional crises, but in the main, political parties, trade unions and interest groups know that their redistributive demands will only be tolerated by other groups if they operate within the constraint of maintaining the viability of the capitalist sector. Not surprisingly, redistributive politics in advanced countries operates through periodic renegotiations of tax and spending priorities within relatively narrow ranges of variation. In contrast, in the typical developing country, the productive capitalist sector is relatively small and the wellbeing of most people in society is not affected by a change in the fortunes of this sector (except in the very long run). Consequently, even if the demands and activities of redistributive groups have serious implications for the economic viability of the productive sector, there are much more limited feedbacks limiting the demands of these groups. Not surprisingly, populist politics and clientelist political factions can persist in their strategies for long periods in developing countries.

These two features of developing countries combine to provide a powerful set of drivers for political corruption that have little to do with the interventionist rentcreation capacities of states and the greed and opportunity cost of public officials involved in rent creation. These drivers are shown in Figure 4. Redistributive demands in developing countries are driven by political factions. The organizational structure of these factions varies from country to country, and this variation has important implications for the extent of these demands and the types of political movements through which they are expressed. At the same time, compared to 
advanced countries, state leaders in developing countries have much more limited formal tax resources to deal with these demands. The standard response of developing country states has therefore been to try and achieve political stability by selecting the most powerful or dangerous factional groups and transferring resources through informal patron-client networks to accommodate these groups.

This results inevitably in political corruption for two reasons. First, most of the resources transferred down these networks are by definition off-budget resources often raised through corruption. In some cases, governing factions engage in corruption or predation and use the proceeds to accommodate powerful clients. In other cases, powerful clients may be allowed to raise resources for themselves through corruption with the state turning a blind eye on these activities. Second, even if some of the resources transferred to selected factions come from legal fiscal sources, their allocation to chosen groups is itself often an act of political corruption. This is because the available resources are typically insufficient for general disbursement to all groups so that their allocation to chosen groups often has to be less than transparent and often has to involve violations of formal rules for the political benefit of the public officials concerned.

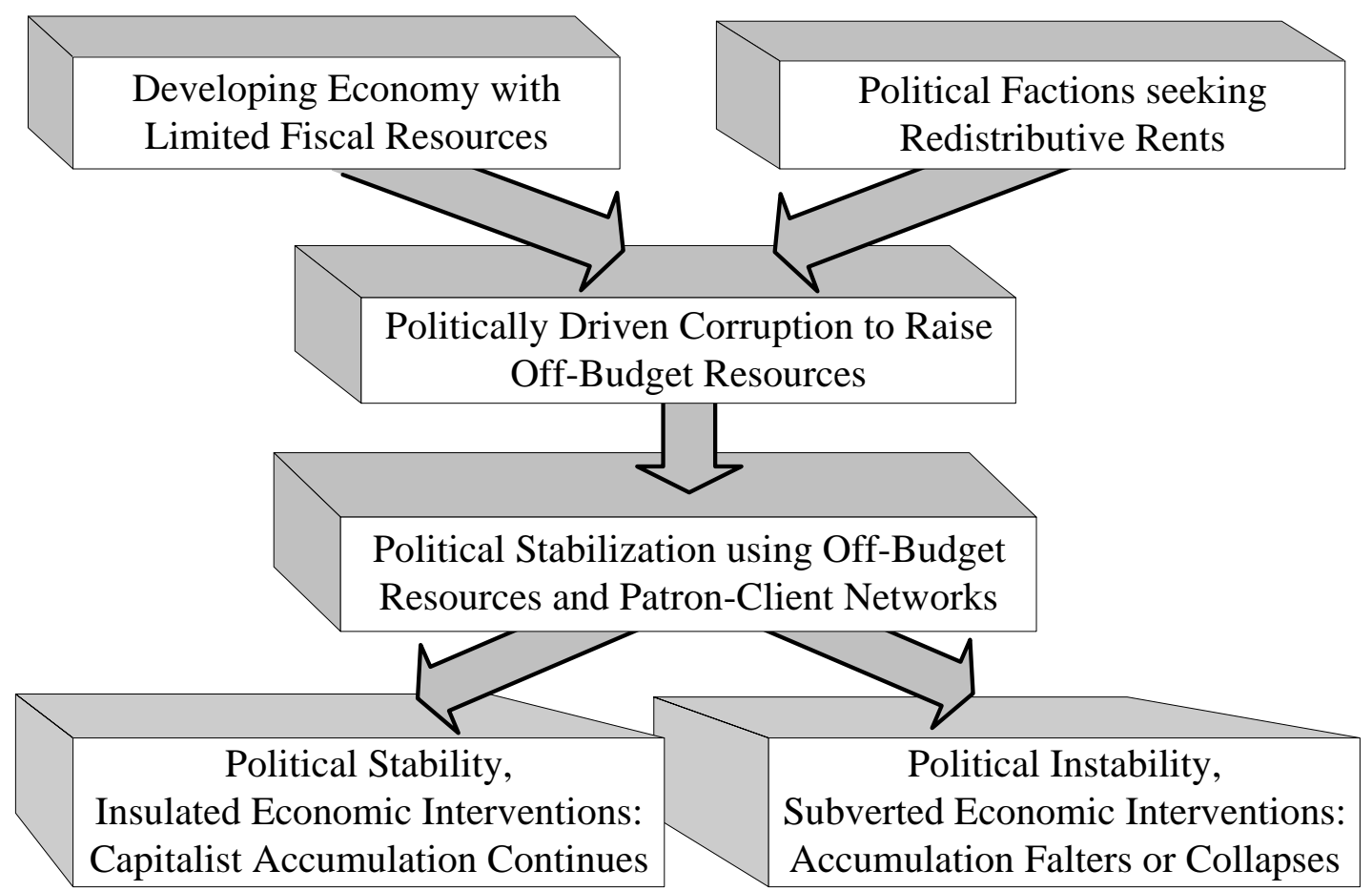

Figure 4 Drivers and Effects of Political Corruption in Developing Countries 
The impact of political corruption depends on the context. In some situations, political corruption can coexist with economic development, as shown along the left hand fork at the bottom of Figure 4. In these cases, the net effect of patron-client politics and political corruption is to achieve enough political stability for the growth of the capitalist sector to continue. A good example of this type of political corruption in a democracy is found in India, particularly in the eighties and nineties (Harriss-White and White 1996, Jenkins 2000, Harriss-White 2003). Here political stability and economic reforms were achieved not because the political system was finally free of political corruption but rather because patron-client networks were used to buy off the opposition using graft and obfuscation. By most accounts, political corruption in India was high and growing during this period. This does not mean that all successful developing countries must suffer from high levels of political corruption. In highgrowth Malaysia, which was moderately democratic in the eighties when growth took off, political corruption was controlled through the construction of an inclusive political coalition that allowed political stabilization through legal transfers to powerful constituencies while still allowing significant growth to happen in the productive sector (Khan 2000b: 98-101). As resources for political stabilization did not have to be raised and allocated outside the budget to the same extent as in other developing countries, Malaysia scored better on corruption indices than many of its peers at a similar level of development. But this was partly due to fortuitous features of Malaysian political economy, including in particular the more significant development of its productive sector before its high-growth period began, which could be taxed both directly and indirectly to generate revenues for redistribution.

But most developing countries suffered from poor economic development and high political corruption as shown at the bottom of the right hand fork in Figure 4. In Africa, it used to be argued that political corruption in the form of neo-patrimonialism was due to the absence of democracy, and that authoritarianism allowed the continuation of personalized politics and the use of informal sources of power by the 'big men’ (Médard 2002). However, it is now more commonly recognized that neopatrimonialism and patron-client networks have survived the transition to democracy in Africa, and they continue to operate with relatively slight modifications (Chabal and Daloz 1999). Elected parties soon realize that staying in power involves 
transmitting resources to powerful constituencies through patron-client networks and if anything, political corruption increased in many of these countries after democratization.

Thus, high-growth and low-growth developing countries do not necessarily differ in terms of the extent of political corruption. Rather, the differences are first that in successful developers, redistributions through political corruption and other mechanisms achieved political stability while in less successful developers stability was not achieved. As a result, the ruling elite can take a long-term view in their policy interventions in successful developers but in the others, the ruling elite have a short time horizon and in extreme cases become predatory. Secondly, an important feature of successful developers is the insulation of critical economic interventions and the associated rents from the political processes through which political rents are allocated. The greater the separation, the greater the chance of sustaining high economic growth as a greater range of critical economic interventions will remain growth enhancing. The extent to which stability is achieved and political redistribution can be isolated from essential economic interventions depends on the structure of patron-client factions in the country, the institutions of representation and the fiscal resources available to the state (Khan 2000b).

Given the drivers of this type of political corruption, it is not surprising that we find that its extent is hardly affected by greater transparency, higher public sector salaries or democratization. The only sustained long term effect on corruption of this type is likely to come from economic development, which is likely to result in a growing fiscal capacity of the state to respond to political demands in open, transparent and generalized ways. Economic development is also likely to lead to a moderation of the demands coming from competing groups demanding redistribution so that economic viability is disrupted to a lesser and lesser extent over time. The comparative evidence supports the view that there are no easy fixes for this type of corruption, which is a major driver of corruption in developing countries. The harm caused by this type of corruption depends on the organization of factional politics, and this can to some extent be altered through political restructuring. But if the aim is to achieve the degree of transparency and fiscal accountability observed in advanced countries, reformers in 
developing countries are setting themselves an impossible task given their fiscal capacity and the factional demands they have to satisfy.

\section{Theft and Primitive Accumulation}

The most pernicious type of corruption in developing countries is predatory corruption by public officials. In this variant of corruption public officials directly, or indirectly through private factions, grab or assist in the grabbing of public resources, such as land or mineral resources, or collude in the extraction of 'protection money' from citizens. This type of predation can be observed in all types of societies, but its incidence is significantly greater in developing countries. Although theft by a private individual would normally not be defined as corruption, when the state colludes in and benefits from theft, or the theft is carried out directly by public officials, this involves corruption because it involves the use of public power for private benefit. In extreme cases, this type of corruption could be associated with a descent into warlordism, where warlords become the de facto state.

Plunder in developing countries is also a systemic problem that seems to be associated with the transitional nature of these economies. Developing countries are typically characterized by a situation in which potentially valuable land and natural resources are owned by low productivity traditional users, often for various forms of collective use. At the same time, most industrial assets are also owned by low-productivity firms. As a result, asset owners collectively cannot produce enough of a surplus to pay for the protection of their assets through the tax system. Individual asset owners who do produce a surplus are forced to make private or semi-private arrangements for protecting their assets, for instance by paying protection money to private mafias, but most asset owners cannot afford this either. In such a context, it is difficult even with the best political will for the state to ensure a satisfactory protection of property rights across the board. The most likely outcome is that the state or parts of it become variants of the mafia, providing private protection at a price to those who can afford it. The difference between predation and protection can very quickly become blurred in these contexts. Much of the police corruption in developing countries takes this more serious predatory form (compared to the neoclassical form discussed earlier), with police and security services often engaging in direct expropriation or allowing expropriation by those who can afford to pay them. With a high degree of 
coordination of the protection services offered by the state, the outcome can be effective protection for privileged asset holders who may even be assisted in capturing further assets from those less able to buy protection. But with high degrees of fragmentation in the provision of protection, the outcome can be sequential extortion even from potentially productive producers by different agencies with the result that the economy collapses.

There are obvious parallels between these processes and the descriptions of 'primitive accumulation' in early capitalism coming from classical political economists, in particular Karl Marx. Marx was referring to non-market transfers during transitions from pre-capitalist to capitalist modes of organizing production. The transfer of assets from pre-capitalist sectors to the emerging capitalist sector has never happened entirely through market exchanges. According to Marx, in the context of the transition to capitalism in England, primitive accumulation involved theft, the enclosure of common lands, colonial plunder, the use of political power to engineer unequal exchange, the protection of markets and transfers through the fiscal mechanism (Marx 1979: 873-940; Wood 2002). Thus, primitive accumulation involves more than plunder, nor is all plunder primitive accumulation. If the ensuing transition takes society in the direction of a viable capitalist economy that can produce a significant economic surplus, this can eventually pay for the protection of the new structure of rights, and the primitive accumulation eventually ends.

Corruption related to the expropriation of property rights is particularly important given the importance attached to the stability of property rights in explaining the poverty of many developing countries (North 1990; Knack and Keefer 1997). However, property rights are unstable and contestable to varying degrees in every developing country, and they have been so in every country during early stages of development. This is not surprising once we identify the structural factors that can explain why involuntary, non-market asset transfers are common in these situations. Stable property rights require a significant public infrastructure of laws, courts and enforcement mechanisms that can ensure that property rights are clearly defined and that their enforcement is a public good that does not depend on individual assetholders spending money to protect specific assets. This infrastructure is an expensive investment, but one that pays for itself over time. The problem for developing 
countries is that existing economic assets are (by definition) not being used in very profitable ways and most economic activities do not produce significant surpluses that could be taxed to provide for the collective enforcement of property rights. This chicken and egg problem can explain why property rights are uniformly weak across developing countries.

The absence of an adequate taxable surplus in developing countries that could allow the protection of property rights as a public good has two interrelated effects. On the one hand, the absence of public resources needed to provide an infrastructure of protection means that many assets are vulnerable to expropriation. Public officials are implicated if they turn a blind eye to the activities of expropriators who provide them with kickbacks or who are their clients. Furthermore, public officials sometimes directly engage in expropriation themselves. On the other hand, the high transaction costs of organizing voluntary sales of assets can prevent the purchase of assets by potentially efficient users from current, less efficient users, even if public officials are not engaged in non-market transfers. The implications of the second effect are very significant. If the possibility of legal contracting is limited because of the high transaction costs of market exchanges, it is possible to explain why many transfers of assets, even in rapidly growing developing countries, take place through non-market mechanisms. These non-market transfers are typically driven by the greed and opportunism of expropriators rather than a calculation of net social benefit. Nevertheless, they may sometimes result in an improvement in asset allocation. This arguably happened in the case of the enclosures and other forms of primitive accumulation that led to the emergence of English capitalism. But equally, if greed and opportunism drive non-market transfers, there is no guarantee that the outcome will be socially beneficial.

In developing counties, powerful groups and factions in society are likely to be engaged in a struggle to restructure ownership and the organization of production or to capture weakly protected assets using their political power. The uncomfortable historical fact is that successful transitions to capitalism did not take place because pre-capitalist property rights were respected and only transferred through voluntary exchanges. Both in rapid developers and in other societies, periods of transition involved significant non-market transfers, but specific and contingent historical 
factors, in particular, pre-existing class and group organizations of some societies ensured that expropriators had incentives and compulsions to invest in productive enterprises and were not themselves subsequently targets of further expropriation. Recent scholarship has pointed out the importance of the configuration of pre-existing social organizations in determining the trajectories of transition in Europe (Wood 2002; Aston and Philpin 1987). Similar differences in social organization can help to explain the differences between successful and less successful transitions in Asia (Khan and Jomo 2000).

The drivers and effects of the corruption associated with theft and primitive accumulation are shown in Figure 5. At first, low-productivity pre-capitalist economic sectors dominate the economy and explain the relatively low taxable surplus available to provide effective protection and enforcement of the underlying rights. The organizational structure of society determines how groups mobilize in response to these weakly defined and contestable rights to expropriate the assets of others or protect their own. We expect to see a wide range of non-market transfers in these contexts, ranging from theft and land grabs that are undoubtedly corrupt to politically organized transfers such as land reform. In between are transfers that are legal but open up possibilities of corruption, such as some privatization strategies, prioritized allocation of land and other resources for specific sectors or uses, and so on. As in the cases of corruption discussed earlier, the outcomes are not predetermined. 

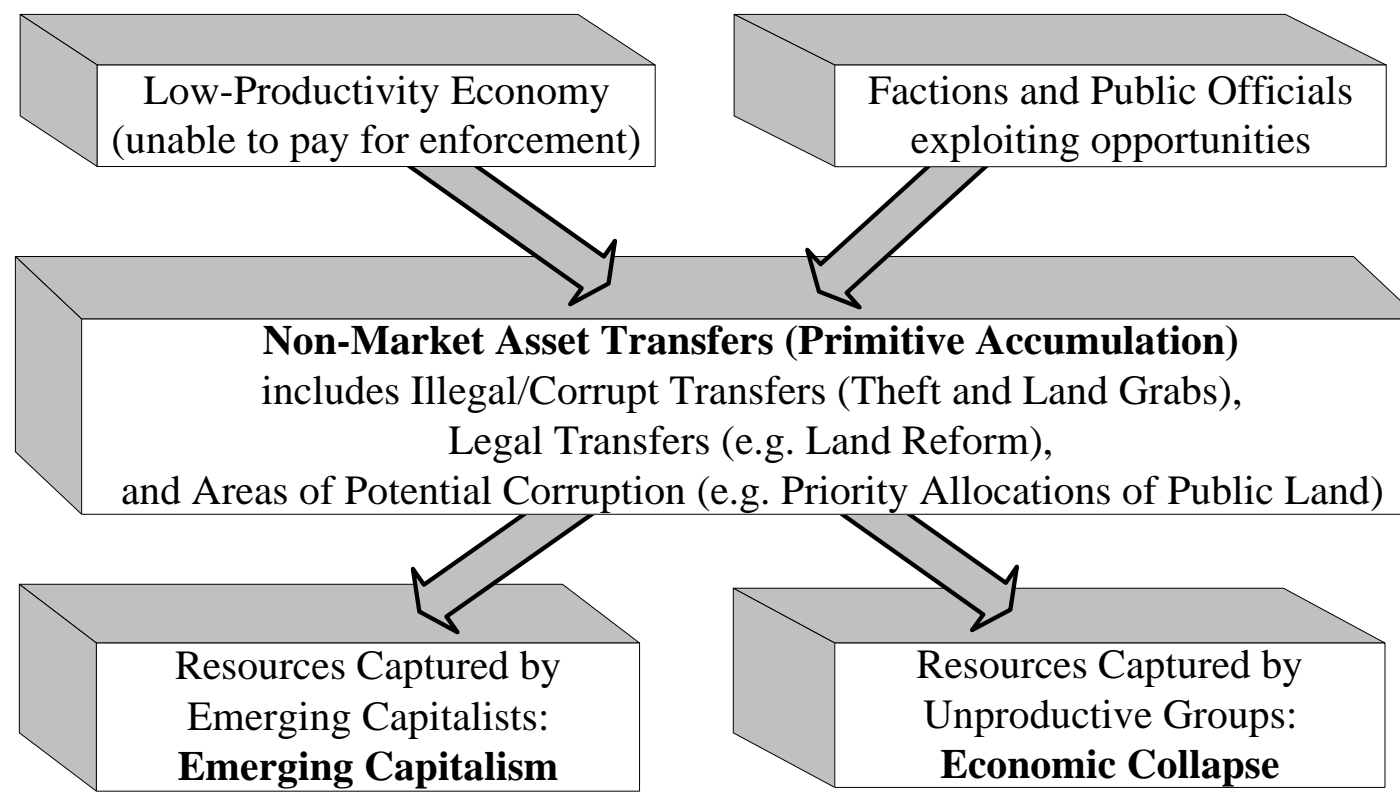

Factions and Public Officials exploiting opportunities

Non-Market Asset Transfers (Primitive Accumulation) includes Illegal/Corrupt Transfers (Theft and Land Grabs),

Legal Transfers (e.g. Land Reform),

and Areas of Potential Corruption (e.g. Priority Allocations of Public Land)

Figure 5 Drivers and Effects of Theft and Primitive Accumulation

If the expropriators of today can subsequently purchase protection at a price that allows them to avoid further expropriation, the period of primitive accumulation could lead to an emerging capitalism. The emerging productive economy can then begin to pay taxes and create state capacities that permit a transition to the stabilization and enforcement of property rights. Unfortunately, the norm in most developing countries is one where expropriators are in turn expropriated, where incentives for productive investments do not emerge, and where the non-market transfers appear to be overtly predatory and destructive for the society's economic prospects. In other cases, as in Russia, expropriators face limited or no compulsions for productivity growth and become instead monopolists who can use their market power to extract from consumers. Here expropriators may be able to pay for the protection of their rights but a second round of redistribution or the construction of institutions that can compel productivity growth may be required to enhance social output.

In a broad sense, expropriation can also be analysed as a variant of rent seeking. The equivalent of the rent here is the asset or income that public officials can expropriate or help others to expropriate using their political or military power. The rent seeking cost is the wasteful use of resources by different groups of expropriators in the course of maintaining their positions of power within or over the state. Despite these similarities with other types of rent seeking, the drivers of this type of corruption are 
very different from those discussed earlier. In particular, expropriation is not based on state capacities to intervene, but rather on the absence of well-defined and wellprotected property rights in society, which in turn create incentives for expropriation.

A focus on reform strategies that aim to address the predatory capacities of the state through greater transparency and accountability and by strengthening the enforcement capacities of the state is unlikely to be effective because the economy does not produce an adequate surplus to pay for the protection of underlying rights. This lack of resources is a critical structural driver of property rights instability that is unlikely to be adequately addressed before a substantial transition to a productive economy has already happened and the required revenues are available for the protection and enforcement of rights across the board. In the meantime, strategies responding to the typically adverse effects of predatory theft and corruption are most likely to work if they can change social organizations and state capacities to ensure that the non-market transfers that characterize every transition lead to a more productive economic structure. Unfortunately, our understanding of these conditions is still very poor and certainly not robust enough to generate reform strategies that are likely to enjoy a wide base of support.

\section{A Classification of Corrupt Transactions}

The discussion so far has distinguished between four types of corruption in developing countries based on differences in the underlying drivers. From a policy perspective, it is useful to present this classification slightly differently. Although all corruption involves the violation of some formal rules of conduct, Table 2 classifies the types of corruption discussed here in terms of the characteristics of underlying state interventions that generate the corrupt behaviour. There are two areas of difference in the underlying state interventions. First, the underlying interventions may be either potentially beneficial or potentially harmful. Second, the underlying interventions may be either legal or illegal. These two sets of differences identify four

distinct types of corruption in Table 2. These distinctions are important for identifying the policies that may be appropriate for dealing with different types of corruption and for identifying types of corruption that may not be amenable to any simple policies in developing countries. 
Table 2. A Typology of Corruption based on Associated Interventions

\begin{tabular}{|c|c|c|}
\hline & Legal Interventions & Illegal Interventions \\
\hline $\begin{array}{c}\text { Potentially } \\
\text { Beneficial } \\
\text { Interventions }\end{array}$ & $\begin{array}{c}\text { 2) Statist Corruption. Net effect can be } \\
\text { beneficial or damaging depending on how } \\
\text { seriously corruption subverts interventions. } \\
\text { Anti-corruption policy should address drivers } \\
\text { to prevent subversion. }\end{array}$ & $\begin{array}{l}\text { 3) Variants of Political Corruption and } \\
\text { Primitive Accumulation. Net effect depends } \\
\text { on degree of political stability achieved, } \\
\text { insulation from economic interventions and } \\
\text { the emergence of productive capitalists. } \\
\text { Anti-corruption policy should seek to increase } \\
\text { likelihood of these outcomes. }\end{array}$ \\
\hline $\begin{array}{c}\text { Damaging } \\
\text { Interventions }\end{array}$ & $\begin{array}{l}\text { 1) Neoclassical Corruption. Net effect of } \\
\text { intervention always negative. } \\
\text { Anti-corruption policy should remove these } \\
\text { state capacities through liberalization and } \\
\text { privatization. }\end{array}$ & $\begin{array}{l}\text { 4) Variants of Political Corruption and } \\
\text { Predation/Theft. Net effect always negative: } \\
\text { possible descent into warlordism and anarchy. } \\
\text { Anti-corruption policy has to strengthen } \\
\text { centralized coercive power of the state. }\end{array}$ \\
\hline
\end{tabular}

The first and simplest type, called neoclassical corruption, is shown in the bottom left hand box in Table 2. Here corruption is associated with the legal capacity of the state to intervene, but these interventions create damaging rents or restrictions in markets. Here, the mainstream policy recommendations of liberalization and privatization together with institutional reforms to increase the opportunity cost of corruption are appropriate. But it is doubtful if this is the most important type of corruption in developing countries. If this is only a part of the corruption problem, and if in addressing this, policies damage the state's development prospects by limiting state intervention, then these policies may hinder, rather than help, the struggle against corruption in the long-run. It is therefore important to assess the relative importance of other types and drivers of corruption before devising policy responses.

The second type of corruption is statist corruption, which is distinguished by being associated with state interventions that are legal and potentially beneficial for society. These interventions include such things as managing taxes and tariffs to accelerate technological progress and catching-up by domestic industry, the regulation of financial markets and the allocation of credit or the prioritization of infrastructure construction. These are precisely the types of interventions that heterodox theories of the state have identified as critical in developing countries going through rapid transitions and catching up with advanced countries. Clearly, corruption in these areas can have a much more significant effect on the economy, both in terms of growth and distribution. Here corruption can reduce the social benefit of the intervention or even 
make the intervention a damaging one. Indeed, in most cases, the subversion and distortion is so severe that ex post many cases of statist corruption may be indistinguishable from neoclassical corruption because the potential benefit of the associated intervention is not obvious. Nevertheless, we have argued that liberalization would not necessarily be the most appropriate response. If potentially useful state functions are subverted, the underlying political economy of why this happens has to be addressed. Otherwise, strategies of state withdrawal risk throwing the baby out with the bathwater.

The right hand column in Table 2 looks at corruption associated with interventions that are not legal and cannot be made legal. All types of political corruption, primitive accumulation and theft would be in one or other of the two right hand boxes, but it is quite important to be able to distinguish between them. The two boxes differ in terms of whether the underlying interventions are potentially beneficial or not. If the illegal interventions associated with the corruption are beneficial for society, as in box 3 , the consequences are likely to be far less serious than if the underlying interventions are damaging as in box 4.

Box 3 describes corrupt transactions arising from potentially beneficial interventions that are not or cannot be made legal include some variants of political corruption and primitive accumulation. We have seen that off-budget political stabilization typically cannot be legal but may be necessary given the inadequacy of fiscal resources and the pressure for political accommodation coming from powerful political factions in society. Similarly, many forms of primitive accumulation cannot be made legal, but these non-market transfers may be necessary to achieve rapid asset re-allocations to users who are more productive. Thus, a subset of both political corruption and of primitive accumulation may be potentially growth enhancing, and even in the presence of substantial corruption may actually be so, given the alternatives. However, the outcomes of these types of interventions are very susceptible to the precise form of the political economy and institutional drivers discussed above.

These drivers may be conducive for economic development and political stability. For instance, the net effect of some types of political corruption may be sufficient political stability for accumulation and growth to continue. The organization of the political 
factions that are accommodated through political corruption may also be such that they can be satisfied through rent allocations that do not require the subversion of necessary economic interventions. Political corruption may then be associated with illegal state actions that are nevertheless consistent with economic development. In the same way, the organization of factions may be such that the primitive accumulation induced by weakly defined property rights allows rapid asset transfers to an emerging productive capitalist class.

In these cases, anti-corruption strategies need to address the issue of converting the illegal rent seeking associated with otherwise beneficial state interventions into legal rent seeking that can be regulated in transparent ways over time. Some of these processes of legalization are made both easier and more necessary by the process of economic development itself. For instance, as economic development proceeds, growing fiscal resources mean that the dirty politics of patron-client alliances and payoffs can be replaced with transparent political stabilization and the stabilization of property rights. At the same time, the growth of interest-based political associations connected to a growing productive sector creates pressures for the political accommodation of broad interest groups rather than of personality-led political factions. This does not mean that the decline of political corruption is necessarily automatic as development proceeds. Here our analysis is different from the modernization theory developed by Samuel Huntington (1968) who argued that development would lead to the reduction of corruption. Economic development creates the conditions necessary for the removal of political corruption and primitive accumulation, but these conditions are by no means sufficient. It is often possible to find examples of political corruption and expropriation of property in relatively advanced countries. Thus, popular pressures for the appropriate institutional reforms are also necessary but are only likely to work once the economic conditions are conducive.

Conversely, pressure alone is not sufficient to reduce political corruption if political power cannot be maintained using fiscal strategies of redistribution, nor can pressure stop primitive accumulation if assets are unproductive and cannot pay for their own protection. Any government will be unable to stabilize a system of property rights that are not viable in the sense of producing a big enough surplus that can pay for their 
protection. In the same way, governments that lack a substantial fiscal base are likely to have to engage in forms of political corruption to distribute off-budget resources to powerful constituencies in order to survive. Political mobilization, democratization and demands for integrity will do little to reduce these types of corruption in most developing countries. In fact, developing countries that have attempted to root out corruption through public mobilization have uniformly failed to make a lasting dent in the problem. Mass movements against government corruption became common in many developing countries from the 1980s onwards. In a number of countries including the Philippines, Indonesia and Bangladesh, mass movements resulted in the toppling of corrupt governments but in all these countries successor governments were soon found to be just as corrupt. In most cases, public mobilization did little to reduce the problem in the long term, though there have sometimes been short-term reductions in corruption because of public pressure.

Much more serious are the cases where political corruption and non-market asset transfers lead to economic collapse, a possibility classified in box 4 in Table 2 . Because the underlying state interventions in this case are damaging as well as being illegal, this is clearly the worst type of corruption. The category is only likely to be important if the social order is breaking down. Public officials are, by definition, engaging in interventions that are directly damaging the economy. Because this hurts the interests of public officials collectively, this type of corruption can only become significant if higher levels of the state have lost control over lower levels, or if the state has begun to fragment horizontally. Once this happens, all types of public officials, from police and security services to political leaders and their factions may engage in expropriation. Although there are aspects of such extortions in every society, it only takes on significant proportions in failed or failing states, which are characterized by the failure of higher levels of the state to discipline lower levels. Some degree of extortion can always take place at lower levels of the state, but where higher levels have the capacity to prevent it, they are not likely to have any interest in allowing this extortion to continue, because it is unlikely to aid their own accumulation and stabilization strategies. If the state can enforce discipline, then even if higher-level bureaucrats and politicians are primarily interested in personal enrichment, they will do better by promoting development rather than predation (Khan 1996a). It is, therefore, very likely that higher levels of the state will engage in 
predatory extortion only if they fail to impose discipline on lower levels and on their clients. Under these conditions, the center can rationally join other expropriators in short-term predation, as they have no better strategy.

Corruption of this type is particularly serious because, just as in the third group, it is difficult to see how such corruption can be realistically addressed before the state has achieved a relatively high degree of development. But here, corruption threatens to prevent the very development that is necessary for its solution. Political corruption here fails to achieve political stabilization. Similarly, contested property rights are captured by expropriators who in turn enjoy little security from other expropriators or have other reasons for having very short time horizons that induce them to consume their gains or invest them outside the country. In these cases, the non-market asset transfers are very different from the primitive accumulation that led to the emergence of capitalism in successful developers, and they are, instead, purely predatory expropriations that are well known in many developing countries.

As a result, countries where these types of corruption are important face very serious challenges that are very unlikely to be resolved using the policy responses appropriate for neoclassical corruption. Unfortunately, the drivers of both political corruption and of primitive accumulation and theft are powerful enough to ensure that attempts to counter these types of corruption through democratization, transparency reforms and state withdrawal from intervention are unlikely to have much effect. In these circumstances, there is a very limited range of drivers that policy can address. Policy can seek to address the complex political economy determining the organization and structure of factional competition. We know there are countries where political reorganization enabled a shift in the division between type 4 and type 3 corruption (Khan 2000b), which can in turn create some of the preconditions for development and thereby help to reduce corruption over time. These examples of political reorganization include the coming to power of Park Chung Hee in South Korea in 1961 and the organization of the National Front government in Malaysia after the riots of 1969. In countries where the fragmentation of the polity has gone some way towards warlordism and anarchy, policy also has to address the political question of how to reconstruct the centralized coercive powers of the state. Far from liberalization, democratization and civil society pressure, the priority in these cases 
has to be a much more fundamental Hobbesian one of constructing the political basis for the state's monopoly of legitimate violence.

\section{Conclusions}

By breaking down corruption into a number of different types, and recognizing their interdependencies, it is possible to explain why the prior reduction of corruption across the board may not be a viable goal for most developing countries. Some types of corruption are simply not going to be significantly reduced in societies going through social transformations, even in societies where such transformations eventually turn out to be successful. At the same time, this is not to deny that corruption is a problem. Very few developing countries have graduated to become dynamic capitalist economies. In poorly performing economies, corruption is damaging because it subverts critical state functions or is associated with failing processes of primitive accumulation or political stabilization. In extreme cases, corruption can be associated with state collapse and a descent into warlordism.

However, our analysis suggests that in each case, the policy response has to be based on identifying the main drivers of corruption and on strengthening state capacities required for achieving rapid transformation and high growth rates. An analysis of governance capacities in high-growth developing economies can play an important role in identifying critical transformational state capacities that may be subverted by specific types of corruption that dominate in particular countries. If the necessary state capacities for accelerating transformation can be achieved, a low-growth economy can transform itself into a high-growth one. Paradoxically, our prediction is that in these countries corruption will coexist with growth for a time until the conditions for dealing with political corruption and asset stabilization are achieved.

The critical question for policy-makers in developing countries is the mix between different types of corruption identified in Table 2 rather than the aggregate level of corruption. Our analysis is consistent with the two observations raised by the crosscountry data summarized in Figure 1, namely that developing countries in general have higher average levels of corruption compared to advanced countries and that high and low growth developing countries do not have significantly different average levels of corruption. The first observation is explained by the fact that advanced 
countries do not have powerful drivers for political corruption and primitive accumulation. Greater tax revenues mean that political stabilization can be achieved with legal rents in the form of transparent fiscal transfers. At the same time, the productive sector generates enough of a surplus to pay taxes for the effective protection of property rights, limiting the possibility of expropriation. Rent seeking nevertheless remains widespread in advanced countries because state interventions (both beneficial and damaging) remain very extensive and there is rent seeking to capture the associated rents. But advanced countries can convert a large part of this rent seeking into legal rent seeking because rent seekers are well established and enjoy much greater legitimacy and can therefore legitimately seek to influence state policy. But, even though advanced countries may have converted a significant amount of corruption into legal rent seeking, this does not mean that they have low rent seeking costs. Moreover, some corruption will always remain but this residual corruption can be controlled by increasing the opportunity cost of corruption for public officials in the way neoclassical analysis suggests.

We explain the second observation by pointing out that although the drivers of political corruption and primitive accumulation ensure that corruption in the aggregate is likely to be high in every developing country, the mix between the different types of political corruption, primitive accumulation and theft shown in Table 2 can vary widely across developing countries. Moreover, the type of political corruption that dominates has interdependent effects on the type of statist corruption. The difference between high and low growth developing countries is rooted in their underlying political structures. In the former, we would expect to see a substantial amount of statist corruption but the state's interventionist capacities have not been entirely subverted by corruption, and corruption occurs along with successful political stabilization and primitive accumulation. There may be some extortion and some neoclassical corruption, but these would be relatively limited, because a coherent state leadership would have nothing to gain by allowing these types of corruption. In contrast, in poorly performing developing countries, we would expect to see damaging political corruption, and predatory asset transfers. As a result, we would also expect statist corruption to be associated with much more distorted interventions and often indistinguishable from neoclassical corruption. It follows that to be effective, the policy debate in poorly performing developing countries has to address 
the political economy drivers of corruption that shift the balance between different types of corruption. Attempts to fight corruption across the board using instruments that are in any case most appropriate for neoclassical corruption are not likely to succeed.

\section{References}

Amsden, Alice 1989. Asia's Next Giant: South Korea and Late Industrialization. Oxford: Oxford University Press.

Aoki, Masahiko, Hyung-Ki Kim and Masahiro Okuno-Fujiwara (eds) 1997. The Role of Government in East Asian Economic Development: Comparative Institutional Analysis. Oxford: Clarendon Press.

Aston, T.H. and C.H.E. Philpin (eds) 1987. The Brenner Debate: Agrarian Class Structure and Economic Development in Pre-Industrial Europe. Cambridge: Cambridge University Press.

Chabal, Patrick and Jean-Pascal Daloz 1999. Africa Works: Disorder as Political Instrument. Oxford and Indianapolis: James Currey and Indiana University Press.

Hall, Robert and Charles Jones 1999. Why Do Some Countries Produce So Much More Output Per Worker Than Others?, Quarterly Journal of Economics 114 (1): 83116.

Harriss-White, Barbara 2003. India Working: Essays on Society and Economy. Cambridge: Cambridge University Press.

Harriss-White, Barbara and Gordon White 1996. Liberalization and the New Corruption, IDS Bulletin 27 (2): 1-5.

Huntington, Samuel P. 1968. Political Order in Changing Societies. New Haven: Yale University Press.

IRIS-3 2000. File of International Country Risk Guide (ICRG) Data, edited by Stephen Knack and the IRIS Center. University of Maryland: College Park.

Jenkins, Rob 2000. Democratic Politics and Economic Reform in India. Cambridge: Cambridge University Press.

Johnson, Simon, Daniel Kaufmann and Pablo Zoido-Lobatón 1998. Regulatory Discretion and the Unofficial Economy, American Economic Review 88 (2): 387-92. 
Kauffman, Daniel, Aart Kraay and Pablo Zoido-Lobatón 1999. Governance Matters. World Bank Policy Working Paper No. 2196. World Bank: Washington.

Khan, Mushtaq H. 1996a. The Efficiency Implications of Corruption, Journal of International Development 8 (5): 683-96.

Khan, Mushtaq H. 1996b. A Typology of Corrupt Transactions in Developing Countries, IDS Bulletin (Liberalization and the New Corruption) 27 (2): 12-21.

Khan, Mushtaq H. 2000a. Rents, Efficiency and Growth, in Khan, Mushtaq H. and K.S. Jomo (eds) Rents, Rent-Seeking and Economic Development: Theory and Evidence in Asia, Cambridge: Cambridge University Press.

Khan, Mushtaq H. 2000b. Rent-seeking as Process, in Khan, Mushtaq H. and K.S. Jomo (eds) Rents, Rent-Seeking and Economic Development: Theory and Evidence in Asia, Cambridge: Cambridge University Press.

Khan, Mushtaq H. 2002. Corruption and Governance in Early Capitalism: World Bank Strategies and their Limitations, in Pincus, J. and J. Winters (eds) Reinventing the World Bank, Ithaca: Cornell University Press.

Khan, Mushtaq H. 2004. State Failure in Developing Countries and Strategies of Institutional Reform, in Tungodden, Bertil, Nicholas Stern and Ivar Kolstad (eds) Toward Pro-Poor Policies: Aid Institutions and Globalization, Proceedings of Annual World Bank Conference on Development Economics, Oxford: Oxford University Press and World Bank. Available HTTP: <http://wwwwds.worldbank.org/servlet/WDS_IBank_Servlet?pcont=details\&eid=000160016_200 40518162841>

Khan, Mushtaq H. and K.S. Jomo (eds) 2000. Rents, Rent-Seeking and Economic Development: Theory and Evidence in Asia. Cambridge: Cambridge University Press.

Klitgaard, Robert 1988. Controlling Corruption. Berkeley: University of California Press.

Knack, Stephen and Philip Keefer 1995. Institutions and Economic Performance: Cross-Country Tests Using Alternative Institutional Measures, Economics and Politics 7 (3): 207-27.

Knack, Stephen and Philip Keefer 1997. Why Don’t Poor Countries Catch Up? A Cross-National Test of an Institutional Explanation, Economic Inquiry 35 (3): 590602.

Krueger, Anne O. 1974. The Political Economy of the Rent-Seeking Society, American Economic Review 64 (3): 291-303.

Lall, Sanjaya and Morris Teubal 1998. "Market-Stimulating” Technology Policies in Developing Countries: a Framework with Examples from East Asia, World Development 26 (8): 1369-85. 
Lambsdorff, Johann Graf 2005. Consequences and Causes of Corruption: What do we Know from a Cross-Section of Countries? Universität Passau

Wirtschaftwissenschaftliche Fakultät Diskussionsbeitrag Nr. V-34-05. University of

Passau: Passau.

Leff, Nathaniel 1964. Economic Development through Bureaucratic Corruption, American Behavioral Scientist 8: 8-14.

Marx, Karl 1979. Capital. Vol. 1. Harmondsworth: Penguin.

Mauro, Paolo 1995. Corruption and Growth, Quarterly Journal of Economics 110 (3): 681-712.

Mauro, Paolo 1997. The Effects of Corruption on Growth, Investment and Government Expenditure: A Cross-Country Analysis, in Elliot, Kimberly A. (ed.) Corruption and the Global Economy, Washington: Institute for International Economics.

Médard, Jean-François 2002. Corruption in the Neo-Patrimonial States of SubSaharan Africa, in Heidenheimer, Arnold J. and Michael Johnston (eds) Political Corruption: Concepts and Contexts, Third Edition, New Brunswick: Transaction Publishers.

Mo, Pak Hung 2001. Corruption and Economic Growth, Journal of Comparative Economics 29 (1): 66-79.

Myrdal, Gunnar 1968. Asian Drama: An Inquiry into the Poverty of Nations. 3 vols. Vol. 2. New York: Pantheon.

North, Douglass C. 1990. Institutions, Institutional Change and Economic Performance. Cambridge: Cambridge University Press.

Rodrik, Dani 1995. Getting Interventions Right: How South Korea and Taiwan Grew Rich, Economic Policy 20: 53-101.

Rodrik, Dani 2002. Institutions, Integration, and Geography: In Search of the Deep Determinants of Economic Growth. Princeton NJ: Princeton University Press. Available HTTP:

<http://ksghome.harvard.edu/ .drodrik.academic.ksg/growthintro.pdf>

Rose-Ackerman, Susan 1978. Corruption: A Study in Political Economy. New York: Academic Press.

Rose-Ackerman, Susan 1999. Corruption and Government: Causes, Consequences and Reform. Cambridge UK: Cambridge University Press.

Shleifer, Andrei and Robert W. Vishny 1993. Corruption, Quarterly Journal of Economics 108 (3): 599-617.

Stiglitz, Joseph E. 1996. Whither Socialism? Cambridge Massachusetts: MIT Press. 
Treisman, Daniel 2000. The Causes of Corruption: A Cross National Study, Journal of Public Economics 76: 399-457.

Wade, Robert 1990. Governing the Market: Economic Theory and the Role of Government in East Asian Industrialization. Princeton: Princeton University Press.

Woo-Cumings, Meredith (ed.) 1999. The Developmental State. Ithaca: Cornell University Press.

Wood, Ellen Meiksins 2002. The Origins of Capitalism: A Longer View. London: Verso.

World Bank 1992. Development and the Environment. World Development Report 1992. World Bank: Washington DC.

World Bank 1997. The State in a Changing World. World Development Report 1997. World Bank: Washington DC.

World Bank 2000. Helping Countries to Combat Corruption: Progress at the World Bank since 1997. World Bank: Washington DC. 